\title{
A METATEORIA E O CONTRAFACTUAL EM RONALD DWORKIN*
}

\author{
Ludmila Lais Costa Lacerda ${ }^{\dagger}$
}

RESUMO: O presente artigo encontra-se no contexto da filosofia do direito e tem como objetivo central reflexão e debate sobre a teoria do direito proposta por Ronald Dworkin. Dworkin propõe uma concepção do direito, distinta daquelas de sua tradição e aponta uma contraposição ao ponto de vista do direito como simples questão de fato, destacando a divergência teórica, o que culmina em críticas às teorias anteriormente apresentadas no campo do direito, na construção de uma teoria a partir do "direito como integridade" e no resgate da responsabilidade humana, através de uma nova proposta permeada de metáforas que levam ao raciocínio contrafactual e à contribuições para a prática decisória.

Palavras-chaves: filosofia do direito - integridade - metáforas - contrafactual - Ronald Dworkin.

\section{METATHEORY AND THE COUNTERFACTUAL IN RONALD DWORKIN}

Abstract: The present article is in the context of philosophy of law and has as its main object reflection and debate on the jurisprudence proposed by Ronald Dworkin. Dworkin proposes a conceptions of law distinct from those of its tradition, draws a contrast to the view of law as a simple matter of fact and highlights to theoretical divergence, which culminates in critical of theories previously presented in the field of law, construction from a theory of "law as integrity" and the rescue of human responsibility, through a new proposal permeated with metaphors that lead to counterfactual reasoning and contributions to decision-making.

Key words: philosophy of law, integrity, metaphors, counterfactual, Ronald Dworkin.

\section{INTRODUÇÃO}

Ronald Dworkin" inicia sua obra "O Império do Direito" ressaltando a importância de análise sobre como os juízes decidem os casos e o que pensam ser o direito, para ele os processos judiciais suscitam (pelo menos) três tipos de questões: de fato, de direito e questões

\footnotetext{
${ }^{*}$ Artigo recebido em 26/03/2013 e a provado em 17/06/2014.

+ Mestre em Direito pela Universidade Federal de Minas Gerais - UFMG (2016). Bacharel em Direito pela Faculdade Mineira de Direito da Pontifícia Universidade Católica de Minas Gerais - PUC-MG (2010). Pesquisadora do Centro de Estudos em Justiça de Transição - UFMG. Pesquisadora (FAPEMIG BGCT.II - nível mestre) na Comissão da Verdade em Minas Gerais (COVEMG) para atendimento ao Projeto de Pesquisa \&quot
} 
interligadas de moralidade política e fidelidade. O autor mencionado propõe que nos casos concretos há entre os juristas a divergência empírica (existência ou inexistência de legislação e precedentes em determinado sentido - mais simples de ser solucionada) e a divergência teórica (se o corpus do direito escrito e das decisões judiciais anteriores esgotam ou não os fundamentos pertinentes do direito - definição sobre o que seja o direito).

Demonstram-se pertinentes os questionamentos sobre o que é o direito, quais seus limites e sobre a possibilidade do magistrado descobrir ou inventar (criar) o direito. Ao julgar os casos os magistrados continuamente confrontam (mesmo que implicitamente) com tais indagações, como exemplo Dworkin cita vários casos (DWORKIN, 1999: 20-38).

Para Dworkin, na prática dos tribunais a divergência empírica é observada, mas a questão da divergência teórica é ignorada pela maioria, sendo que esta maioria trata o direito como simples questão de fato, limitando-se apenas à ideia que o juiz faça cumprir "a lei" (texto da lei em seus limites semânticos) como sendo sinônimo do "direito" sem preocupação com a justiça, ou que, na falta da lei para solução de determinados casos (suposta lacuna) o juiz exerça seu discernimento para criar norma (de acordo com sua sabedoria e seu senso de justiça). Tanto na interpretação (adequação / extensão / restrição) de textos das legislações e dos precedentes existentes para aplicação aos casos, quanto na decisão de casos inéditos se faz presente a discricionariedade (em diferentes graus - fraca/forte). A discricionariedade e seus "graus" estarão caracterizados e delimitados de acordo com o embasamento teórico, modo de interpretação de textos existentes e conjunto da argumentação utilizada na decisão.

Assim, inicialmente Dworkin aponta uma contraposição ao ponto de vista do direito como simples questão de fato ao descaso à divergência teórica, o que culmina em críticas às teorias anteriormente apresentadas no campo do direito (teorias semânticas do direito DWORKIN, 1999: 40) e no resgate da responsabilidade humana através de uma nova proposta permeada de metáforas que levam ao raciocínio contrafactual e à contribuições para a prática decisória.

\section{A CRÍTICA TEÓRICA DE RONALD DWORKIN}

A teoria proposta por Ronald Dworkin enfrenta o tema da divergência teórica a partir da análise do exercício da justiça pelos juízes nas decisões judiciais, ou seja, através da prática nos tribunais, vez que "o direito é a nossa instituição social mais estruturada e 
reveladora. Se compreendermos melhor a natureza de nosso argumento jurídico, saberemos melhor que tipo de pessoas somos" (DWORKIN, 1999: 15).

Dworkin vai além da perspectiva analítica, da divisão entre 'ser' e 'dever ser' e da busca por cognições descritivas ou críticas normativas do direito a partir de um observador externo com pretensão de uma teoria neutra. No direito como integridade há um resgate de demonstrações do direito por meio da prática nas decisões judiciais (como produtos da argumentação, interpretação, das práticas sociais, da história e do tempo) que revelam impossibilidade da neutralidade de teorias semânticas sobre o direito, visto que tanto estas teorias (concepções do direito) quanto seus autores (observadores) estarão sempre imersos em um contexto histórico e portanto limitados, marcados pelo tempo e por pré-compreensões (GADAMER, 1997).

As teorias semânticas do direito partem do pressuposto que os advogados e juízes utilizam os mesmos critérios para determinar se uma proposição jurídica é verdadeira ou falsa, ou seja, nas teorias semânticas acredita-se que os envolvidos na prática jurídica estão de acordo a respeito dos fundamentos do direito (o que é o direito - os fundamentos do direito seriam o que as instituições já decidiram no passado).

Assim, para os teóricos do positivismo jurídico a verdadeira divergência sobre a natureza do direito seria uma divergência empírica sobre a história das instituições jurídicas (exemplos: para Austin uma proposição jurídica é verdadeira se conseguir transmitir o comando de um soberano, que detém o poder e que todos obedecem, mas que não obedece a ninguém - para H. Hart os fundamentos do direito encontram-se na aceitação, a verdade das proposições jurídicas não está na soberania da autoridade, mas sim na chamada regra mestra ou de reconhecimento, em que se atribui/delega a competência/autoridade para elaborar novas normas), tal perspectiva de divergência leva a um fator de análise subjetiva (interna) do direito (se essas teorias partem da consideração que o direito é mera reprodução do que as instituições decidiram no passado, elas questionam o modo pelo qual tais determinações são aceitas/legitimadas pelas pessoas - confiança, reconhecimento, coação, medo, etc). Considerando a perspectiva positivista, a legitimidade das normas é trabalhada no aspecto de sua procedência, ficando a racionalidade de seu conteúdo em plano distinto.

Já na escola do direito natural as divergências sobre o fundamento do direito e validade das preposições jurídicas estariam em questões de critérios morais e não inteiramente factuais. Há também a corrente do realismo jurídico, que permite a previsão de prováveis e 
possíveis decisões de acordo com variados contextos, assim, o fundamento do direito e determinação da validade das proposições jurídicas dependem de resultados calculados pelo magistrado, os adeptos dessa corrente afirmam que "o direito" (como sendo o conjunto textos que as instituições já decidiram no passado - positivismo) não existe (o que existem são somente decisões judiciais a serem proferidas considerando as probabilidades e cálculos futuros argumentados pelo magistrado - não há vinculação ao passado), ou que resulta apenas daquilo que "o juiz tomou em seu café da manhã" (DWORKIN, 1999: 45).

A partir de casos concretos: Elmer, Snail Darter, McLoughlin e Brown (DWORKIN, 1999: 20-38) fica demonstrado que na prática verdadeiramente há uma divergência teórica quanto aos fundamentos do direito (em contrapartida ao que é identificado pelos positivistas como sendo o direito), principalmente quando considerados insuficientes os textos literais das legislações e/ou precedentes para resolução dos casos inéditos e quando estes envolvem interesses econômicos e/ou políticos.

As discussões travadas nos casos mencionados demonstram que o direito não se esgota na existência de leis/precedentes e seus textos, nem em um questionamento sobre os juízes seguirem somente tais dispositivos em suas respostas, mas vai além, pois, mesmo que haja observância às leis/precedentes é inevitável que estes tenham seus textos interpretados e, possivelmente dotados de diferentes sentidos construídos a cada decisão judicial em caso(s) concreto(s) conforme suas peculiaridades, essa possibilidade interpretativa na construção da decisão é que colabora para proporcionar legitimidade às leis/precedentes e às próprias decisões judiciais de forma argumentativa.

Em defesa da afirmação de que na prática dos tribunais existe um acordo (prévio) a respeito dos fundamentos do direito, os positivistas afirmam que os casos relatados (inéditos) teriam um debate disfarçado sobre qual deveria ser a natureza do direito, predominando sempre afirmação que "o direito" existe (legislação ou precedente anteriormente expresso) e que o juiz deve segui-lo. Na falta do direito positivado para aplicação em determinados casos, o juiz poderia julgar livremente de acordo com seu entendimento (pois o "direito" the permite expressamente essa atitude discricionária) utilizando argumentos do que na verdade 'deveria ser' um possível texto (direito positivado) sobre determinado caso novo.

Ou seja, para os positivistas, nas respostas dos casos citados não havia 'direito' (leis/precedentes anteriores) a ser descoberto, diante das "lacunas" nos casos apresentados as soluções não teriam vindo do "direito" diretamente, mas sim de um debate simulado. Nesse 
debate os juízes mencionam o "direito" vigente (leis/precedentes existentes) e sob alegação que este não se enquadra perfeitamente à resposta do caso, os juízes (investidos de autoridade para tanto através de leis/“direito" positivo) criam e aplicam soluções discricionárias pautadas no que eles entenderem que o 'direito' deveria vir a ser.

Há também uma defesa com recurso à imprecisão da linguagem e diversidade de sentidos para uma mesma palavra em determinados casos ou contextos, ela mostra que os juízes não estariam fingindo, mas divergindo quanto ao conteúdo do direito naquele determinado caso (ao que o direito deveria ser), apontando o problema apenas para a escolha e utilização de uma palavra cujo significado não tem limites fixos. Ocorre que, o uso de poder do Estado não pode se reduzir a um mero jogo de palavras.

As teses de defesa do positivismo não bastam para lidar com os casos apresentados, porque os juízes divergiram não somente de modo superficial quanto à validade das preposições jurídicas, mas também divergiram em relação à sua essência e aplicação.

Constata-se que: (1) $\mathrm{Na}$ prática jurídica há uma superação do direito como somente aquilo que a lei diz, ou seja, o direito não se resume apenas no que as instituições jurídicas decidiram no passado em textos de leis e/ou precedentes. (2) As leis/precedentes em si mesmas (na literalidade de seus textos) não possuem necessariamente as respostas corretas para os casos. (3) Os limites semânticos dos textos das leis/precedentes não impedem que haja interpretação, pelo contrário, tais textos carecem de interpretação para que os casos sejam respondidos, mas não é por isso que será cabível qualquer tipo de interpretação. (4) De acordo com o positivismo, ao magistrado, diante do caso concreto, seria permitido adotar em sua resposta: uma postura restritiva, ainda justificada pelas bases positivistas, considerando seus argumentos limitados pelo texto expresso da lei/precedente através de uma análise semântica de seus comandos (para o magistrado a resposta ao caso estaria expressa na "letra da lei"); ou caberia ao magistrado se posicionar de modo ativo quando entendesse estar diante das "lacunas" (a resposta do caso não estaria expressa na "letra da lei"), the sendo permitido (pelo ‘direito' - leis/precedentes expressos) criar de modo irrestrito a solução para os casos.

Dworkin propõe que não é possível mera postura restritiva pelo magistrado, pois a subsunção não é autoevidente, assim, a interpretação não é uma questão optativa e sim imprescindível, uma vez que a norma não existe por si e a cada vez que é aplicada (mesmo em sua "literalidade" e com seus limites semânticos) necessariamente é interpretada (GADAMER, 1997: 461), precisando ser contextualizada e ter suas finalidades justificadas. 
De tal modo, não haveriam lacunas a serem preenchidas pelo magistrado de modo discricionário (completamente livre e desvinculado), pois a cada caso, na construção de cada decisão, seriam interpretadas as leis/precedentes existentes e à priori cabíveis, bem como, justificadas suas "(in)suficiências" para responder corretamente o caso à luz de uma reconstrução histórica (coerente) das leis/precedentes aludidos e aplicáveis ao caso concreto e às práticas sociais em questão, além disso, haveriam os princípios como "trunfos", para solução e resposta nos julgamentos de casos com maior complexidade (ou inéditos).

O direito foi apresentado pelo positivismo como um sistema de regras que parece convencer pela simplicidade, mas torna-se incompatível com a complexa e sofisticada prática do direito. A ineficácia de tal explicação para casos concretos os remete à teoria do poder discricionário, segundo a qual, diante da ausência de uma regra de direito estabelecida anteriormente por uma instituição competente e claramente aplicável ao caso, o juiz teria permissão para criar respostas e aplicá-las de modo retroativo, ou seja, 'legislar' especificamente para o caso.

$\mathrm{O}$ positivismo de Hart sustentou que o direito seria um conjunto de regras identificadas por meio de uma única regra de reconhecimento. Afirmou ainda que, esse conjunto de regras válidas esgotaria o conteúdo do direito e, não havendo regra clara que seja identificada pela regra de reconhecimento ao caso concreto, os juízes teriam poder discricionário para decidir. Defendeu igualmente que, os direitos e obrigações poderiam originar-se somente de regras jurídicas as quais seriam validadas pela regra de reconhecimento. Consequentemente, nos casos em que não haja regras jurídicas validadas pela regra de reconhecimento, não se poderia sustentar que uma das partes do litígio teria direito a alguma decisão a seu favor.

Para Dworkin o conteúdo do direito não se esgotaria em um conjunto de regras, e nem poderia ser totalmente identificado (delimitado) por uma regra de reconhecimento, pois na legislação e na prática jurídica existiriam, também, "princípios" que possuiriam estrutura e funcionamento distintos das regras e que poderiam ser aplicados pelos juízes aos casos. Assim, diante dos princípios (também considerados como integrantes do direito), os juízes não possuiriam possibilidade criativa (discricionariedade - forte) nas soluções dos casos.

Para a tese dworkiniana independente da divergência e argumentações apresentadas pelas duas partes em um caso haverá sempre uma resposta correta, o juiz não realizará mera escolha entre os argumentos apresentados pelas partes mediante critério de verdade ou 
validade, mas apresentará a melhor resposta (correta/adequada) ao caso como seu ofício exige. Ainda que inexista regra claramente aplicável ao caso, uma das partes pode ter o direito de ganhar a causa, pois, além da existência dos princípios, em todos os casos o juiz tem o dever de realizar uma construção argumentativa sobre os direitos das partes culminando na resposta correta, e não de inventar novas regras retroativamente (DWORKIN, 2002: 127).

No paradigma do Estado Democrático de Direito a perspectiva democrática e luta contra arbitrariedades coaduna com a integridade proposta por Dworkin (tese da resposta correta) em contraposição à discricionariedade judicial e ao positivismo que cogitam a possibilidade de escolhas aleatórias pelo juiz e tomadas de decisões antidemocráticas (com usurpação do poder legislativo) e injustas (com aplicação de normas retroativas criadas pelos juízes após o fato).

Tendo por base as críticas tecidas ao positivismo e o direito como integridade, é possível dizer que Dworkin considera a prática judicial associada a moral, de forma que não há uma relação de neutralidade entre direito e moral. Habermas (2003, p. 257) afirma a insuficiência do procedimento de normatização como legal para que haja legitimidade. A validade do direito ocorre a partir da sua justificação, para tanto, Dworkin se apoia nos princípios.

Dworkin fundamenta distinção nos discursos, onde defende a primazia dos argumentos de princípios que remetem aos conteúdos morais dos direitos fundamentais, sobre a argumentação de políticas, que são cunhadas para a concretização de objetivos em relação à supostos bens coletivos. O Legislativo é a porta de entrada dos argumentos éticos e pragmáticos próprios das políticas públicas, possivelmente incorporados ao discurso judicial de forma seletiva e condicionada, dado o papel de "firewall" dos direitos fundamentais de linguagem deontológica, no ordenamento jurídico. (CARVALHO NETTO, SCOTTI, 2011: 58)

Thomas Bustamante (BUSTAMANTE, 2008) ressalta que é possível entender as críticas ao positivismo (pós-positivismo) como tipo de teoria jurídica que não nega "a utilidade e a razoabilidade dos critérios positivos utilizados pelas teorias positivistas", mas também os utiliza indiretamente (através da crítica) para identificar (e refutar) determinado(s) tipo(s) de postura(s) teórica(s) sobre o direito. Assim, a partir de um campo teórico já delineado (pelo positivismo), o pós-positivismo pôde transcender tais limites de pensamento (positivista), negando a tese de separação entre direito e moral. 
De tal modo, é possível considerar que o pós-positivismo (diferente do jusnaturalismo) tem em suas teorias uma estrutura crítica a partir da noção de "positivismo" e de seus principais critérios para delimitar o conceito de direito (a validade formal e a eficácia social), o que culmina em: uma superação (ir além) de análise do direito com a consideração da prática e incorporação dos princípios; e na contraposição à tese da separação entre direito e moral, e também contraposição à tese da discricionariedade (no sentido positivista - forte, com possibilidade de livre criação pelo magistrado das soluções dos casos "aparentemente" sem resposta no "direito"). Importante esclarecer nesse ponto que, mesmo a expressão "positivismo" estando no singular, deve-se observar que esta se refere a uma pluralidade de declarações diferentes sobre o direito, mas que sustentam bases semelhantes de critérios para delimitação do direito e separação entre direito e moral (BUSTAMANTE, 2008). Na obra "O Império do Direito", Dworkin faz críticas ao grupo de teorias semânticas do direito, que podem agrupar principalmente as teorias positivistas, teorias da escola do direito natural e da escola do realismo jurídico.

Ainda de acordo com Bustamante (2008), "o debate entre positivistas e póspositivistas gira em torno tanto de uma divergência teórica sobre o conceito de direito quanto também, e talvez até num grau mais intenso, em torno de uma diferença metateórica". Com isso, "o positivista e o pós-positivista divergem não apenas quanto ao objeto de estudo da teoria jurídica - o direito - mas também quanto às próprias tarefas, propósitos e justificativas das suas construções teóricas".

Em uma visão hermenêutica propiciada por Gadamer, Dworkin parte da tradição, ou seja, das teorias e concepções "do direito" anteriores a ele, para pensar o direito e construir sua proposta teórica alternativa.

Apesar de criticar as teorias semânticas em sentido geral, Dworkin se dedica em especial à teoria positivista de H. L. A. Hart, no sexto capítulo do livro "A Justiça de Toga" (2010: 199). Na obra Dworkin aponta que, para a teoria de Hart, em toda comunidade onde houvesse discussões sobre alegações de direito, a grande maioria das autoridades aceitaria como uma convenção alguma "regra de reconhecimento dominante" para "identificar quais fatos ou eventos históricos, ou de outra natureza, tornam verdadeiras as alegações de direito".

Para Dworkin essa convenção (regra de reconhecimento dominante) inexiste uma vez que, não há critérios comuns que possam endossar ou rejeitar proposições do direito (conceitos políticos, exemplo: liberdade, democracia, justiça, direito, não tem uma estrutura 
natural padrão imutável a ser descoberta, descrita e seguida como absoluta, verdadeira "DNA"), ainda propõe que a teoria de Hart "não constitui uma descrição neutra da prática jurídica, mas uma interpretação dela que pretende não apenas descrevê-la, mas também justificá-la", tal teoria é valorativa, pois "toma partido em favor daqueles que insistem que os direitos jurídicos das partes devem ser estabelecidos mediante consulta às fontes tradicionais do direito" (DWORKIN, 2010: 200 e 232-233).

Assim, Hart estaria equivocado ao se considerar em uma posição externa (observador privilegiado e neutro) para construir sua teoria, não se colocando como mais um participante das atividades jurídicas. Dworkin defende que o florescer da filosofia do direito é imanente à prática social e à prática jurídica e chama de "filosofia arquimediana" a metodologia usada por filósofos como Hart que a partir de pressupostos (convenções pré-existentes) e/ou na busca por uma "neutralidade" pretendem lançar "um olhar de superioridade, de fora e de cima, sobre a moral, a política, o direito, a ciência e a arte" fazendo distinção entre o discurso ("primeira ordem") dos não filósofos - do discurso ("segunda ordem de 'meta'discurso") dos filósofos, que exploram as afirmações de primeira ordem as classificam e atribuem categorias.

O primeiro filósofo a apresentar uma versão sistemática do positivismo jurídico, Jeremy Bentham, esperava que pudesse na prática jurídica acabar com o poder político dos juízes, exercido em casos que eram extrapoladas as declarações explícitas do Parlamento (Congresso do povo). As transformações tecnológicas e inovações comerciais ao longo dos séculos exigiram mais do que o provimento do direito positivo (principalmente após a Segunda Guerra Mundial), com isso, os juízes e as outras autoridades judiciais passaram a voltar-se para "princípios de estratégia e justiça", almejando a evolução do direito de acordo com as novas necessidades das práticas sociais. Portanto, "parece artificial e despropositado negar que esses princípios também participem do que é o direito" (DWORKIN, 2010: 300).

Os positivistas contemporâneos não resistem à expansão dos direitos individuais com uma concepção majoritária do direito (como Bentham), ao contrário, afirmam que o positivismo não impõe limites ao que fazem os juízes e autoridades. Em um "isolamento intelectual" restringem a filosofia do direito como tema e profissão independente e autossuficiente, não se esforçando "para associar a filosofia do direito à filosofia política e à prática jurídica, erudição e teorias substantivas” (DWORKIN, 2010: 301).

Dworkin (2010: 302) menciona que desde Hart, os positivistas (inclusive o próprio Hart) defendem que a filosofia do direito, como modalidade geral, é desenvolvida de modo 
independente, com delimitações específicas e difere não apenas da prática, mas também dos campos particulares: substantivo e processual do direito. A filosofia do direito seria conceitual e descritiva (não substantiva e normativa), portanto distinta e independente da filosofia política. Também, (por ser conceitual) seria diferente da sociologia do direito ou antropologia jurídica que seriam disciplinas empíricas.

Por fim, Hart e Dworkin tem divergências sobre (im)possibilidade de uma teoria "neutra", além dos modos de identificação do direito e até que ponto e em que sentido os juristas e os juízes devem emitir seus próprios "juízos de valor" para realizar essa identificação nos casos e julgá-los. Conceder discricionariedade ao juiz conforme a teoria de Hart provocaria decisões antidemocráticas, pois o juiz estaria ocupando o lugar do legislativo (que possui seus representantes eleitos pelo povo) e decisões injustas, pois os juízes estariam aplicando retroativamente as normas criadas por eles para os casos específicos ou inéditos.

Para Dworkin não se pode alegar que a análise filosófica de um valor é "conceitual, neutra e desengajada", mas sim "normativa, engajada e conceitual". Para entender verdadeiramente o que é liberdade, democracia, direito ou justiça, deve-se buscar "a identificação do valor de um valor". Assim, "uma descrição bem-sucedida de qualquer valor é realizada com a descrição desse valor do modo como ele existe e funciona no contexto de um esquema de valores compartilhados" (DWORKIN, 2010: 220-221, 252).

\section{O DIREITO COMO INTEGRIDADE}

Em “O Império do Direito" Dworkin desenvolve uma teoria da interpretação, a qual expressa a prática do direito, a partir da interpretação construtiva, na procura em fazer a melhor interpretação possível do que algo possa ser, ou seja, há tentativa de "apresentar o conjunto da jurisdição em sua melhor luz, para alcançar o equilibrio entre a jurisdição tal como o encontram e a melhor justificação dessa prática” (DWORKIN, 1999: 112).

Especialmente no capítulo II ("Conceitos de interpretação") da mencionada obra, em uma parte intitulada "etapas da interpretação" (DWORKIN, 1999: 81-82), pode ser encontrada a divisão das três etapas de interpretação: etapa pré-interpretativa, etapa interpretativa e etapa pós-interpretativa. A primeira identifica "as regras e padrões que se consideram fornecer o conteúdo experimental da prática”. A segunda estabelece uma justificação dos princípios que se ajustam às práticas em questão, visando garantir que se 
obtenha uma "interpretação" e não uma "invenção". Por fim, a terceira etapa reforma a prática para que esta se adapte.

Todo este processo constitui estágios em que o juiz identifica as regras e normas que constituem a prática social estabelecida concernente ao caso que demanda deliberação, bem como, apresenta uma justificativa para os elementos anteriormente evocados. E, por fim, chega a uma decisão que melhor se ajusta à prática social enraizada em uma dada comunidade regulada por um ordenamento jurídico comum.

A partir das considerações sobre interpretação, são apresentadas três concepções de direito na prática: o convencionalismo, o pragmatismo jurídico e o direito como integridade.

Para a concepção convencionalista a prática jurídica consiste no cumprimento de convenções do passado determinadas por instituições e inexistindo convenções jurídicas que tratem de determinado tema, inexistem direitos, devendo o juiz usar seu poder discricionário para criar novo direito. Lembramos que, conforme Dworkin, o conteúdo das convenções sempre passará por uma questão interpretativa e que o direito é muito mais amplo do que o estabelecido em convenções jurídicas, inexistindo margem para a aplicação da discricionariedade.

No pragmatismo afirma-se que os juízes decidem de acordo com o que thes pareçam melhor para o futuro da sociedade, sendo desnecessária qualquer coerência com o passado. Fica demonstrado caráter fortemente discricionário e ameaça à segurança jurídica não respeitando as fontes do direito positivadas, nem os princípios jurídicos, a "melhor comunidade do futuro" se encontra nas mãos dos juízes de acordo com tal concepção.

$\mathrm{O}$ direito como integridade é uma teoria alternativa às anteriores, onde as afirmações jurídicas voltam-se tanto para o passado quanto para o futuro e que recusa descoberta de um direito pré-existente (convencionalismo) ou invenção de um direito novo (pragmatismo), pois coloca a prática jurídica melhor compreendida quando se reconhece que as decisões judiciais contêm as duas coisas e nenhuma delas.

Para construção de sua teoria, Dworkin utiliza de metáforas na tentativa que seu intérprete capture a essência das experiências comunicadas e as aplique em sua prática, a partir de uma substituição analógica. A palavra metáfora tem a mesma raiz de "ânfora", um recipiente usado para guardar e transportar óleos e condimentos de um lugar para outro (LAKOFF e JOHNSON, 2002), de modo semelhante, as metáforas parecem conter ideias e ensinamentos valiosos tendo a capacidade de conservá-los e potencial de transmiti-los no 
decorrer do tempo.

Assim, para demonstrar a importância de coerência (histórica) na prática jurídica, uma das metáforas utilizadas na teoria da integridade é o "romance em cadeia" (chain novel) onde o juiz em sua atividade é comparado a um crítico literário que, procura interpretar as diversas dimensões de valor em uma obra ou peça teatral. De tal modo, o magistrado faz parte de um grupo de romancistas responsáveis por escrever um romance em série, sendo que, cada romancista interpreta os capítulos anteriores para dar início à escrita de um novo capítulo, assim, cada um deve escrever seu capítulo de modo a contribuir para um todo coerente (DWORKIN, 1999: 276).

A escolha pelo gênero narrativo em prosa na modalidade romance abdica das formas clássicas e não se liga a subjetividade do lírico, tragédia do dramático ou objetividade do épico, dando lugar à escrita da realidade e do hodierno a cada tempo.

Diante do jogo entre tradição (passado), novidade (futuro) e imediato (presente), o "romance em cadeia" demonstra necessidade de encadeamento da narrativa jurídica, onde considerado o conjunto da obra, cada (novo) capítulo escrito mantém plausibilidade com as partes produzidas por diversos juízes e cortes, o que pode ser mais facilmente exequível em ordenamentos que exijam a consideração do precedente como parte da argumentação.

Assim, uma argumentação jurídica inspirada no "romance em cadeia" não pode negligenciar interpretação dos debates escritos em diversos capítulos por distintos autores na cadeia do romance jurídico e a obra não pode conter capítulos isolados em que juízes atuem desprezando os precedentes, escrevendo argumentos restritos apenas ao texto das leis como cânones e/ou recorrendo exclusivamente a argumentos políticos no momento de elaboração de tais legislações, essa postura desvinculada comprometeria justamente a segurança jurídica e a visão constitutiva da justiça, uma vez que a busca daquilo que o legislador/autor quis dizer separado de outros elementos desnatura as conexões históricas e despreza as contribuições (não criações por si) que o intérprete/romancista/magistrado pode oferecer.

Além disso, ao se valer somente de argumentos políticos pautados na intenção do legislador no momento de ações políticas, o juiz estaria desconsiderando que seria necessário um equilibrio de opiniões, já que os legisladores divergem entre si, desconsideraria também que no momento de elaboração das leis os legisladores poderiam estar sendo levados por suas próprias opiniões e convicções ou negociações e grupos de interesses particulares (apesar de se esperar que além dos juízes os legisladores de uma comunidade ajam com base em 
princípios e com integridade, o histórico da legislatura é limitado para servir de base exclusiva às pretensões argumentativas na construção da decisão correta, servindo a priori apenas à tentativa de apontar as convicções que justificaram o que os legisladores fizeram).

Salutar mencionar um apontamento feito por Dworkin (1999: 62-63): a busca por uma interpretação exclusiva do autor como revelação plena da obra já foi alvo de crítica de Gadamer. Habermas (1987: 92-93), ainda apontou em Gadamer uma visão por demais passiva se a hermenêutica assumisse o fluxo comunicativo como unilateral (obra - interpretes), Habermas justifica que a interpretação pressupõe que também o autor poderia aprender com o intérprete sobre a obra e seus sentidos.

Em uma visão íntegra do direito há importância na memória e em seu acesso através das decisões, o que fica demonstrado diante da exigência que as novas decisões não somente levem em consideração decisões passadas (não somente as descrevendo / reproduzindo), mas que contenham também uma recuperação das narrativas construídas pelo encadeamento de decisões pretéritas, realizando argumentativamente na nova decisão uma (des)construção (DERRIDA,2002: 46-54) e (re)construção das decisões passadas, as (re)interpretando de modo crítico e as aperfeiçoando à luz principalmente das exigências do caso concreto (em questão), das práticas sociais e da tradição.

A partir do resgate da memória é possível que além de uma formação coerente e encadeada do direito, haja desenvolvimento da identidade do próprio povo. Sendo a memória coletiva a lembrança de acontecimentos, ela exige como suporte discursos intersubjetivos tecidos na esfera pública e operados com uma construção/reconstrução contínua mediante a interpretação.

Também como um dos pilares para a construção da decisão jurídica além do romance em cadeia, Dworkin lança mão da: "comunidade de princípios". Afinal, as decisões ao longo do romance em cadeia são construídas para (e também por) uma sociedade que aceita a integridade como virtude, se transformando em um "tipo especial de comunidade" que desenvolve sua autoridade moral para assumir e mobilizar a força coercitiva. A comunidade de princípios segue a ideia que as pessoas aceitam um governo não por regras expressas estabelecidas por decisões políticas tomadas no passado, mas por quaisquer outras 'regras', que possam decorrer dos princípios que essas decisões pressupõem.

Assim, o conjunto de normas públicas reconhecidas pode expandir-se e contrair-se de modo orgânico, à medida que as pessoas da comunidade tornem-se mais sofisticadas em 
perceber e explorar o que esses princípios exigem a cada nova circunstância, sem necessidade de constantes reformas e detalhamentos rígidos da legislação ou jurisprudência sobre cada um dos possíveis pontos de conflito (DWORKIN,1999: 229).

Para expor a complexa estrutura da interpretação jurídica Dworkin utiliza "um juiz imaginário, de capacidade e paciência sobre-humanos, que aceita o direito como integridade. Vamos chamá-lo de Hércules" (DWORKIN, 1999: 287). Para apresentar a figura do magistrado que através da atividade interpretativa e a partir da comunidade de princípios e do romance em cadeia constrói a resposta correta aos casos, Dworkin utiliza de outra metáfora: "o juiz Hércules", inspirada pela história do herói mitológico Hércules (Héracles para os gregos).

Tal conto (HORTA, NOGUEIRA e BOTELHO, 2012) descreve que Héracles foi um extraordinário mortal (tanto que após sua morte foi convertido em semideus) filho de Zeus e Alcmena (neta de Perseu) foi odiado por Hera - a rainha do Olimpo. Héracles foi anunciado como Rei de Micenas antes de seu nascimento, mas às vésperas de tal fato Hera o destronou. Após manipular para Zeus fazer um juramento que a primeira criança a nascer naquele dia assumiria os mandos da Casa Real de Perseu, Hera retardou o parto de Héracles e apressou o de seu primo Euristeu, este nasceu primeiro e assumiu o trono. Desde jovem Héracles já era um guerreiro letal e graças a suas façanhas ganhou a mão de Mégara com quem teve seis filhos. Hera em mais um ato contra o herói invocou Atê (deusa da loucura) que lançou a sombra da insanidade sobre Héracles fazendo com que em um surto ele se equivocasse e matasse seus próprios filhos.

Abandonado e arrasado pela dor e culpa, Héracles foi ao Oráculo que como expiação ordenou que ele se curvasse a serviço de Euristeu (seu primo e Rei de Micenas, covarde e invejoso que vivia no ócio e luxo) o Rei ordenou à Héracles doze missões mortais e impossíveis de executar à primeira vista (Os Doze Trabalhos de Héracles). Após ser dispensado por Euristeu e se remir cumprindo as 12 tarefas, Héracles desposou Dejanira, esta quase foi raptada por um centauro que se disse apaixonado por ela, Héracles derrubou o centauro com flechas envenenadas, antes de morrer o ser entregou sua túnica com seu sangue a Dejanira prometendo que seu marido a amaria para sempre se colocasse tal vestimenta, pois estava com sangue de um coração que ela dominara. Assim ocorreu. Um dia desconfiada do fim do amor de Héracles sua esposa lhe enviou a túnica, ocorre que a vestimenta estava na verdade embebida de sangue e também de veneno (causador da morte do centauro). Ao usar a 
veste e imediatamente tentar destroça-la Héracles, tomado de dor, acabou por arrancar as próprias carnes e no desespero do sofrimento se lançou sobre feches de lenha implorando que alguém the ateasse fogo, o que foi feito por um de seus discípulos.

$\mathrm{Na}$ esteira do mito, Dworkin descreve (contrafactualmente) o juiz Hércules como um magistrado com capacidade e paciência sobre-humana, que não se deixa abater pelo tamanho da tarefa e por ser persistente e dedicado não vai abdicar da decisão, ou seja, não passará o problema adiante, além disso, o juiz Hércules é responsável em construir para cada caso a sua correta resposta assim como o Héracles da mitologia grega se empenhou para buscar uma solução inteligente e específica para cada trabalho considerado inexequível, dentre os doze que the foram ordenados.

Em contrapartida ao juiz dotado de tantas qualidades e tão próximo à dedicação e perfeição encontra-se a falibilidade humana, que é admitida, mas trabalhada por Dworkin quando ele explica o motivo para querer se utilizar de 'Hércules' e não de outro exemplo extraído da falibilidade judicial: (1) utilizar-se de um exemplo falível seria admitir que por "desventura e com frequência" os juízes tomarão decisões injustas não adiantando que eles se esforçassem para chegar a decisões justas; (2) por serem considerados falhos, poderia entender-se que os juízes "não precisam fazer esforço algum para determinar os direitos institucionais das partes diante deles", devendo decidir os casos com "base em razões políticas ou, simplesmente, não decidi-los". O que o autor considera como perverso. Assim, ficaria aberta a possibilidade que os juízes submetessem a outros órgãos as questões de direito colocadas pelos casos sem aparente ou clara resposta em leis /precedentes. Mas, se fosse assim, submeter tais casos a quem? (DWORKIN, 2007: 203) Poderia o judiciário se eximir de julgar?

Ainda sim, a figura do juiz Hércules suscita uma crítica pertinente feita por Habermas (1997: 276-277) à Dworkin: A impossibilidade de se conceber o direito de uma comunidade feito por um só narrador e a "solidão" de Hércules ao decidir "sozinho" demonstrariam a falta de pressupostos de uma teoria do discurso. Tal crítica se mostra infundada se analisada a teoria de Dworkin em seu conjunto, pois tanto o juiz Hércules quanto os diversos autores do romance em cadeia são os membros dessa comunidade, tendo sua visão formada por esse mesmo "pano de fundo de silêncio compartilhado" (CARVALHO NETTO, 1999: 473) que rege as práticas sociais. Assim, retomando uma das metáforas ora retratada, qual seja $a$ comunidade de princípios, percebe-se que o juiz Hércules também faz parte dessa 
comunidade, interagindo e desenvolvendo suas tarefas a partir dessa realidade. Ademais, não haveria qualquer outro interlocutor que se esmerasse mais que juiz Hércules na construção do direito como integridade.

Os críticos da metáfora de Hércules não percebem que as atribuições dele decorrem de um recorte no trabalho de Dworkin, que alerta os leitores ao afirmar que seu projeto é limitado também nesse sentido, pois "concentra-se na decisão judicial, nos juízes togados, mas estes não são os únicos protagonistas nem mesmo os mais importantes" (DWORKIN, 1999: 16-19). Dworkin ainda ressalta que "ainda que os juízes devam ter a última palavra, sua palavra não será melhor por esta razão" (DWORKIN, 1999: 492), pois os juízes têm o dever de descobrir quais são os direitos das partes, e não inventar novos direitos e aplicá-los de modo retroativo (DWORKIN, 2002: 127), assim o juiz real deve suprir sua desvantagem em relação a Hércules recorrendo aos participantes e garantindo o trânsito livre de comunicação na prática jurídica (DWORKIN, 1999: 114).

Pontuado o papel filosófico, a origem e a necessidade da metáfora do juiz Hércules para a teoria do direito como integridade, passa-se à análise do modo como o juiz Hércules realizará seu trabalho. Hércules é um juiz que aceita as leis e acredita que os juízes têm o dever geral de considerar e desenvolver as decisões anteriores de seu tribunal ou dos tribunais superiores. Assim, em primeiro lugar, o juiz Hércules "estudará a Constituição", procurando entender as regras que ela contém e as interpretações judiciais anteriores, além da filosofia política que embasa os direitos ali dispostos (DWORKIN, 2002: 165-168). Depois disso procurará a interpretação que vincula de modo mais satisfatório o disposto pelo legislativo a partir das leis promulgadas e sua responsabilidade como juiz (DWORKIN, 2002: 169).

Diante do caso concreto o juiz Hércules precisa se empenhar ao trabalhar as possíveis leis aplicáveis ao caso para formar uma ponte entre a justificação política da ideia geral de que as leis contêm direitos e qual(is) direito(s) específico(s) está(ão) representado(s) por uma lei específica no caso examinado. Para tanto, "ele utiliza uma teoria política" para interpretar a lei e esclarecer sua(s) finalidade(s) (DWORKIN, 2002: 168-171), se perguntando ainda qual(is) argumento(s) de princípio $e$ de política convenceria(m) o poder legislativo a promulgar a lei sob estudo. Também é criado elo entre os princípios (comunidade de princípios) e as regras positivas do direito para justificar suas aplicações aos casos.

Para analisar uma lei, Hércules tratará o Congresso como um autor anterior a ele na cadeia do Direito. Todavia Hércules deverá procurar a melhor interpretação da lei, analisando 
também o histórico desta lei. Abordará as declarações oficiais dos legisladores e atos políticos relacionados ao texto que pretende interpretar. A interpretação construtiva de Dworkin (2003, 377-380) contrapõe-se à interpretação conversacional, a qual procura aceitar o ponto de vista da intenção do locutor. Hércules perceberá as "declarações de propósitos oficiais" como decisões políticas, englobando-as na interpretação das leis (DWORKIN, 2003: 410).

Aprofundando o processo exposto no livro Levando os Direitos à Sério, a integridade exige que Hércules elabore uma justificativa para a aplicação da lei. Essa justificativa deve ser coerente com o restante da legislação vigente (DWORKIN, 2003: 407). Hércules interpreta não só o texto da lei, mas também sua vida, o processo que se inicia antes que ela se transforme em lei e se estende para além desse momento.

Para interpretação da Constituição outro modo é necessário, tendo em vista que a Constituição é um tipo especial de norma. Os tribunais superiores têm o poder de julgar a compatibilidade de uma norma ou ação governamental com a Constituição, um poder bastante amplo e que deve ser utilizado respeitando as virtudes políticas. Ao tratar de normas constitucionais, Hércules não se considera nem um passivista nem um ativista. Acredita, assim como em outros casos, que "sob o regime do direito como integridade, os problemas constitucionais polêmicos pedem uma interpretação, não uma emenda" (DWORKIN, 2003: 442).

Qualquer interpretação competente da Constituição como um todo deve reconhecer que alguns direitos constitucionais se destinam a impedir que as maiorias sigam suas próprias convicções quanto ao que a justiça requer. O julgamento interpretativo de Hércules exigirá o envolvimento das virtudes políticas e a averiguação de compatibilidade delas com os mandamentos constitucionais (DWORKIN, 2003: 442-450). Inicia seu processo interpretativo pesquisando uma teoria de interpretação e após uma que se aplique aos fins constitucionais, sempre sujeita a revisões posteriores. Uma interpretação feita a partir do princípio da integridade respeita as limitações institucionais, quais sejam a supremacia legislativa e o precedente (DWORKIN, 2003: 472- 479).

Importante ressaltar que, conforme dito, quando Hércules interpreta as leis e considera juridicamente argumentos de princípio ou de política que possam fornecer a melhor justificação da lei à luz das responsabilidades do poder legislativo, porém ele usa a política para justificar direitos criados pelo legislativo e não sua decisão. As decisões são justificadas mediante argumentos de princípio, tanto que, quando interpreta as decisões judiciais 
passadas (questão a seguir), Hércules atribui relevância apenas aos argumentos de princípio, pois a tese dos direitos sustenta que tais argumentos correspondem corretamente à responsabilidade do tribunal em que foram promulgadas (DWORKIN, 2002: 173).

Adiante em sua busca pela melhor resposta, juiz Hércules faz análise dos precedentes relacionáveis ao caso. Ao analisar os precedentes, Hércules levará em conta os argumentos de princípio que o embasaram. Relembrando que sua interpretação das decisões judiciais será diferente de sua interpretação das leis em um aspecto importante. Ao estudar os precedentes, Hércules terá que distinguir sua força gravitacional nas decisões posteriores. Segundo Dworkin, a força gravitacional de um precedente repousa na equidade, nesse prisma, casos semelhantes são tratados do mesmo modo (DWORKIN, 2002: 176). Para definir a força gravitacional de um precedente, o juiz Hércules somente leva em consideração os argumentos de princípio que justifiquem esse precedente.

Ainda como desdobramento dos seus estudos sobre os precedentes, o magistrado constrói uma sequencia de princípios que fundamentam de maneira coerente o direito costumeiro, a partir de justificações dadas nas decisões pretéritas (DWORKIN, 2002: 181182). Essa tarefa hercúlea inicia-se com uma retomada de seus julgamentos ao especificar a teoria constitucional que já utilizou quando se perguntou sobre quais responsabilidades o sistema político lança sobre o legislador (DWORKIN, 2002: 183).

Mesmo seguindo toda uma construção para decidir o caso, Hércules sabe da possibilidade de encontrar decisões incoerentes. Por isso precisa também de uma teoria sobre os erros, ele construirá a primeira parte dessa teoria por meio de dois conjuntos de distinções. Distinguirá autoridade específica, que é o poder de produzir efeitos de uma lei ou precedente, ou decisão executiva, das consequências institucionais, que definem o seu poder gravitacional. E fará uma segunda distinção que trata de primeiro: erros enraizados, onde apesar da perda de poder gravitacional, efeitos específicos continuam sendo gerados, e segundo: erros passíveis de correção, cuja perda do poder gravitacional gera a perda da autoridade específica (DWORKIN, 2002: 189-190). O nível constitucional de sua teoria irá determinar quais são os erros enraizados.

A segunda parte da sua teoria sobre os erros deve demonstrar que sua existência, reconhecimento, desenvolvimento e aplicação se mostram mais benéficos do que o não reconhecimento dos erros ou o reconhecimento dos erros de uma forma diferente (DWORKIN, 2002: 190). O juiz Hércules utilizará duas ordens de argumentos para 
demonstrar que certa corrente jurisprudencial está errada. Valer-se-á de argumentos históricos ou de uma percepção geral da comunidade, para demonstrar que determinado princípio anteriormente e historicamente importante, no momento da decisão não é mais valorizado da mesma forma, não exerce força suficiente para gerar uma decisão jurídica. Também utilizará argumentos de moralidade política, demonstrando que tal decisão ou princípio fere a equidade, ou seja, é injusto (DWORKIN, 2002: 191).

De forma resumida, o caminho feito por Hércules para encontrar a resposta correta a um problema jurídico inicialmente é: (1) trabalhar com coerência argumentos e justificações os direitos em conflito; (2) Selecionar as hipóteses principiológicas que possam corresponder à melhor interpretação do histórico das leis e decisões anteriores, caso haja mais de uma hipótese é necessário encontrar uma correta; (3) Encontrar a hipótese correta a partir do pensamento de que o direito é estruturado por um conjunto coerente de princípios. A partir da coerência é possível encontrar uma resposta satisfatória quando princípios conflitam (DWORKIN, 2003: 253); (4) Colocar a interpretação à prova. Perguntar-se-á se essa interpretação é coerente o bastante para justificar as estruturas e decisões políticas anteriores de sua comunidade (DWORKIN, 2003: 288-294).

\section{CONCLUSÃO}

A partir da ideia que para haver discussão e divergência a respeito de "algo" não é preciso que haja também um consenso preexistente do que é esse "algo", até porque a própria discussão ou divergência advém (pode advir) justamente da inexistência desse consenso, Ronald Dworkin cria a expressão do aguilhão semântico (DWORKIN, 1999: 55). O aguilhão tem a finalidade de demonstrar os riscos em adotar como pressuposto a ideia de existência de um consenso semântico, principalmente quanto "ao que é o direito" para o desenvolvimento de teorias a partir desse referencial impreciso, tomadas pelo equívoco que o direito é mero fato social totalmente separado da moral na prática. Para Dworkin todas as teorias do direito (exceto a sua) são marcadas pelo aguilhão semântico (LEITER, 2004: 8).

Após as análises realizadas, são propostas algumas questões finais: qual(is) o(s) principal(is) aspecto(s) na construção da teoria do direito de Ronald Dworkin difere(m) de outras teorias (semânticas do direito)? A não pressuposição da existência de um consenso sobre o que é o direito na prática? A consideração complementar entre moral e direito? A 
negativa de poder discricionário ao juiz para emitir seus próprios juízos de valor nos casos complexos (inéditos)? A abordagem da disciplina "filosofia do direito" como não isolada e não autossuficiente demonstrando importância da prática para o seu desenvolvimento? A utilização de recursos como as metáforas, o contrafactual? Todas essas considerações juntas (e outras além)? Dworkin representa com o juiz Hércules (e demais metáforas) um referencial como "método" de interpretar o direito e construir decisões? Essa teoria seria "incorruptível" (impassível de distorção e subjetividades) em sua aplicação pelos juízes?

Sem pretensões de responder todas as perguntas suscitadas nesse tópico com completude, mas apenas na tentativa de iniciar essa "missão hercúlea", podemos dizer que Gadamer observa que na modernidade, a valorização do método e razão instrumental ignoram a tradição. Para Gadamer o método tem que se reconciliar com a tradição, pois o passado estabelece relação com a razão, o que elimina a ideia de neutralidade no julgamento. Há uma limitação definida pelos parâmetros da tradição, não sendo possível à razão ignorar o contexto de quem julga.

Em sua origem, o fenômeno hermenêutico não é problema do método (GADAMER, 2007: 29). A questão não está em submeter às obras a um método de compreensão científico, mas em se compreender a tradição, não se compreende apenas obras, mas também é necessário discernimento e reconhecimento de contingentes verdades: "com a experiência da filosofia, com a experiência da arte, da própria historia. São modos de experiência nos quais se manifesta uma verdade que não pode ser verificada com os meios metodológicos da ciência" (GADAMER, 2007: 29-30). Pode ser que Dworkin como gadameriano tenha entendido que "o que é o direito", assim como as decisões judiciais, não são pensados e construídos através de equações matemáticas ou fórmulas prontas, mas que são ideais e ao mesmo tempo frutos da constante (re)construção da tradição através da compreensão humana e do enlace contínuo entre história e sociedade no tempo. De acordo com Dworkin (1999: 14):

"Em momentos de menos reserva, porém, contarão uma história diferente, mais romântica. Dirão que direito é instinto, que não vem explicitado numa doutrina, que só pode ser identificado por meio de técnicas especiais cuja descrição ideal é impressionista, quando não misteriosa. Dirão que julgar é uma arte, não uma ciência, que o bom juiz mistura analogia, ciência, sabedoria política e a consciência de seu papel para chegar a uma decisão intuitiva, que ele "vê" o direito com mais clareza do que consegue explicá-lo, de tal modo que sua opinião escrita, por mais cuidadosamente racional que possa ser, nunca será capaz de apreender a plenitude de seu discernimento". 
É preciso afirmar que Dworkin não faz distinção entre regras e princípios de forma abstrata a partir de critérios morfológicos, mas sim lógico-argumentativos diante caso concreto. Em um caso concreto, na aplicação entre duas regras, ou se aplica uma regra ou outra (critérios de escolha pré-determinados), os princípios (através da adequação e reconstrução correta do caso), são aplicados de modo unitário (em uma concorrência não cabe aplicação de dois ou mais princípios para solução de um caso).

Tal consideração remete a uma afirmação de cunho habermasiano quanto à diferença entre normas e valores: (1) as normas (princípios e regras) seriam enunciados deontológicos (levam ao devido), em contraposição, (2) os valores são enunciados axiológicos (levam ao bom, melhor ou preferível).

$\mathrm{Na}$ solução dos casos Dworkin aplica os princípios como deontológicos, ou seja, pelo critério do devido, não permitindo duas ou mais princípios sejam adotados para a resolução de um caso concreto, o que ensejaria critério de preferência. Ao proceder de tal forma Dworkin não contradiz a natureza dos princípios com sua aplicação e mantém o seu código binário, não os transformando em código gradual e em valores (axiológicos) no momento de aplicação, o que reforça a coerência de sua teoria.

Após críticas ao positivismo em suas variadas formas e em uma composição mais abrangente que aquelas presentes em sua tradição, Dworkin constrói sua teoria, que considera $o$ direito como prática interpretativa e construtiva. Dworkin procura demonstrar que a filosofia do direito não é uma disciplina desvinculada da prática, e que através desse reconhecimento é possível desenvolver a filosofia do direito e a prática de forma mais profunda, esclarecedora e íntegra. Assim, mediante os princípios e a prática interpretativa do direito não há espaço ou lacuna para o poder discricionário dos juízes (subjetividade). É possível constatar que a metáfora do "juiz Hércules" reúne elementos do passado e do futuro: utilização do nome de um herói com história desde a antiguidade para representar e traçar um parâmetro, exemplo inspirador a ser seguido pelos juízes reais na atividade judicante.

\section{NOTAS}

${ }^{1}$ Ronald Dworkin (Worcester, Massachusetts, 11 de dezembro de 1931 - Londres, 14 de fevereiro de 2013) foi um Filósofo do Direito. Estudou na Harvard University e no Magdalen College - University of Oxford. Atuou como assistente do renomado juiz Learned Hand na 'United States Court of Appeals for the Second Circuit'. Trabalhou como advogado em 'Sullivan and Cromwell', um importante 
escritório de advocacia de New York. Na Yale University Law School (1962-1969) foi titular da Cátedra de Teoria do Direito (Jurisprudence) 'Wesley N. Hohfeld'. Na University of Oxford (1969) foi indicado para a Cátedra de Teoria do Direito como sucessor de H.L.A. Hart. (em 1998 aposentouse da cátedra de Oxford). Na New York University School of Law (desde o final dos anos 1970) é professor de Direito. Nessa mesma universidade (desde 1985) ocupa a Cátedra 'Frank Henry Sommer Professor of Law' e é professor de Filosofia. Na University College London - UCL (após 1984) passou a ser professor visitante, onde em 1998, assumiu a Cátedra 'Quain Professor of Jurisprudence at University College London', tendo posteriormente, em 2005, ocupado a Cátedra de Teoria do Direito 'Jeremy Bentham' na mesma universidade, que até hoje mantém. É membro da British Academy e da American Academy of Arts and Sciences. Principais publicações: Taking Rights Seriously (1977); A Matter of Principle (1985); Law's Empire (1986); Issues in Senile Dementia (1987); A Bill of Rights for Britain (1990); Life's Dominion (1993); Freedom's Law: the Moral Reading of the American Constitution (1996); Sovereign Virtue. The Theory and Practice of Equality (2000); Justice in Robes (2006); Is Democracy Possible Here? Principles for a New Political Debate (2006); Justice for Hedgehogs (2011). Dworkin escreveu a partir dos anos 70, no contexto de uma crise de confiança que assolou o mundo ocidental à medida que suas metanarrativas e suas instituições passaram a ser questionadas. Particularmente nos Estados Unidos, a guerra do Vietnã e o caso Watergate fizeram com que muitas pessoas perdessem a confiança na conduta dos governos. A teoria jurídica não mais podia ser pensada simplesmente como "filosofia jurídica", várias correntes de pensamento implicavam que a política subjacente do direito deveria se tornar visível. A ideia tradicional de felicidade, equidade e justiça pareciam estar sendo substituídas por cálculos de maximização da riqueza. O Estado precisava de maior clareza e reformulação para manter sua credibilidade intelectual. Um problema surgia: "Como a autoridade da filosofia jurídica podia ser ( $\mathrm{r}$ )estabelecida diante do declínio do objetivismo que o positivismo parecera oferecer? (<http://pt.wikipedia.org/wiki/Ronald_Dworkin>

$<$ http://www.ucl.ac.uk/laws/academics/profiles/index.shtml?dworkin>

$<$ http://its.law.nyu.edu/facultyprofiles/profile.cfm?personID=1989> (acesso em 01-11-2012); MORRISON, Wayne. Filosofia do direito: dos gregos ao pós-modernismo. São Paulo: Martins Fontes, 2006, p. 496).

\section{REFERÊNCIAS BIBLIOGRÁFICAS}

BULFINCH, Thomas. O livro de ouro da mitologia: história de deuses e heróis. 34. ed. Rio de Janeiro: Ediouro, 2006.

BUSTAMANTE, Thomas da Rosa de. Uma defesa do pós-positivismo. Virtú. Revista virtual de Filosofia Jurídica e Teoria Constitucional, n. 2, Março 2008, p. 1-40.

Disponível em: <http://br.vlex.com/vid/uma-defesa-pos-positivismo-58965999>. Acesso em 01 novembro 2012.

BUStamante, Thomas da Rosa de. Teoria do Precedente Judicial: A justificação e a aplicação das regras jurisprudenciais. 1. ed. São Paulo: Noeses, 2012.

CARVALHO NETTO, Menelick de. Requisitos pragmáticos da interpretação jurídica sob o paradigma do Estado Democrático de Direito. In: Revista de Direito Comparado. Belo Horizonte. Curso de Pós-Graduação em Direito da UFMG e Mandamentos. v. 3, maio/1999. 
CARVALHO NETTO, Menelick de.; SCOTTI, Guilherme. Os direitos fundamentais e a (in)certeza do direito. A produtividade das tensões principiológicas e a superação do sistema de regras. Belo Horizonte: Forum, 2011.

DERRIDA, Jacques. Declarations of independence. In: ROTTEMBERG, Elizabeth (Ed.). Negotiations: Interventions and interviews - 1971-2001. Stanford: Stanford University Press, 2002.

DWORKIN, Ronald. O Império do Direito. São Paulo: Martins Fontes, 1999.

DWORKIN, Ronald. Levando os Direitos a Sério. São Paulo: Martins Fontes, 2002.

DWORKIN, Ronald. O Império do Direito. São Paulo: Martins Fontes, 2003.

DWORKIN, Ronald. Levando os Direitos a Sério. São Paulo: Martins Fontes, 2007.

DWORKIN, Ronald. A Justiça de Toga. São Paulo: Martins Fontes, 2010;

FERNANDES, Bernardo Gonçalves. Curso de Direito Constitucional. 3. ed. Rio de Janeiro: Lumen Juris, 2011;

GADAMER, Hans-Georg. Verdade e método: traços fundamentais de uma hermenêutica filosófica. 3. ed. Petrópolis: Editora Vozes, 1997.

GADAMER, Hans-Georg. O problema da consciência histórica. Tradução de Paulo César Duque Estrada. 2. ed. Rio de Janeiro: Editora FGV, 2003.

GADAMER, Hans-Georg.. Hermenêutica em retrospectiva. Petrópolis, RJ: Vozes, 2007.

HABERMAS, Jürgen. Dialética e hermenêutica. Porto Alegre: L\&PM, 1987.

HABERMAS, Jürgen. Direito e democracia: entre faticidade e validade. Rio de Janeiro: Tempo Brasileiro, 1997.

HABERMAS, Jürgen. Direito e democracia: entre faticidade e validade. 2. ed. Rio de Janeiro: Tempo Brasileiro, 2003.

HART, H. L. A. O Conceito de Direito. São Paulo: Martins Fontes, 2009.

HORTA, Maurício; NOGUEIRA, Salvador.; BOTELHO, José Francisco. Mitologia: Deuses, Lendas, Heróis. Superinteressante Coleções, São Paulo: Editora Abril, 2012.

LAKOFF, George.; JOHNSON, Mark. Metáforas da vida cotidiana. São Paulo: Mercado das Letras, EDUC, 2002.

LEITER, Brian. The End of Empire: Dworkin and Jurisprudence in the 21st Century. Texas, $\quad$ n. 70, 2004. Disponível em: 
$<$ http://papers.ssrn.com/sol3/papers.cfm?abstract_id=598265>. Acesso em: 17 dezembro 2012.

MORRISSON, Wayne. Ronald Dworkin e a luta contra o desencanto: ou o direito na ética interpretativa da filosofia do direito liberal. IN: Filosofia do Direito: dos Gregos ao Pósmodernismo. São Paulo: Martins Fontes, 2006, p. 495-534.

RAZ, Joseph. Two Views on the Nature of the Theory of Law. IN: Jules Coleman and Ori Simchen, Hart's Postscript. 2003.

WITTGENSTEIN, Ludwig. Investigações filosóficas. Tradução de José Carlos Bruni. São Paulo: Nova Cultural, 1999. 